\title{
Resistance Exercise in Prostate Cancer Patients: a Short Review
}

\author{
Andrej Zdravkovic ${ }^{1} \cdot$ Timothy Hasenoehrl $^{1} \cdot$ Richard Crevenna $^{1}$
}

Accepted: 13 January 2021 / Published online: 30 January 2021

(C) The Author(s) 2021

\begin{abstract}
Purpose of Review The aim of this paper is to provide an overview of recent findings concerning the utilization of resistance exercise (RE) in prostate cancer (PCa), in particular as pertaining to the management of cancer therapy side effects.

Recent Findings As of late, studies investigating the effects of RE in PCa patients have found positive effects on muscle strength, body composition, physical functioning, quality of life, and fatigue. The combination of RE and impact training appears to decrease the loss of bone mineral density. RE seems to be well accepted and tolerated, even by patients with bone metastatic disease, although a modification of the RE prescription is often necessary.

Summary In PCa patients, RE has been well-researched and the data are clear that it is beneficial in multiple ways. Future directions should look at the long-term effects of RE, including mortality and relapse, as well as implementation of exercise programs.
\end{abstract}

Keywords Resistance training $\cdot$ Exercise oncology $\cdot$ Prostatic neoplasms $\cdot$ Prostate cancer $\cdot$ Androgen antagonists

\section{Introduction}

\section{The Impact of Prostate Cancer and Its Therapy}

Prostate cancer $(\mathrm{PCa})$ is one of the most common oncologic diseases worldwide [1] with an increasing incidence and prevalence especially in younger males [2]. In recent years, the mortality of PCa has improved in most countries for which data is available [3•]. The therapy for $\mathrm{PCa}$, particularly for hormone-dependent variants, usually includes androgen deprivation therapy (ADT), and its side effects often present as loss of muscle mass, increase in fat mass, insulin resistance, sexual dysfunction and loss of libido, gynecomastia, hot flashes, anemia, fatigue and potentially increases in cardiovascular and metabolic disease risk $[4,5]$. Due to the improving survival rates, the potential long-term side effects of ADT are steadily gaining the attention of the scientific community [6]. Recent studies suggest that only a minority of $\mathrm{PCa}$ patients

This article is part of the Topical Collection on Cancer Rehabilitation

Richard Crevenna

richard.crevenna@meduniwien.ac.at

1 Department of Physical Medicine, Rehabilitation and Occupational Medicine, Medical University of Vienna, Waehringer Guertel 18-20, A-1090 Vienna, Austria
(PCaP) die of the malignant disease, the predominant cause of death being cardiovascular disease, among other comorbidities [7,8]. Correspondingly, all-cause mortality increases with an increasing number of comorbidities in $\mathrm{PCaP}$, whereas the disease-specific mortality remains relatively constant [8]. Consequently, the mitigation of the side effects of PCa therapy, which can largely be achieved by exercise, notably resistance exercise (RE), is a rapidly growing field of research.

\section{History of Resistance Exercise in Cancer}

After many years of recommendations to "rest and recover," one of the earliest aerobic exercise (AE) interventions was reported in 1989, investigating the effects on body composition [9] and functional capacity [10] in breast cancer patients, paving the path for the emerging field of exercise oncology. Unfortunately, and most probably due to misconceptions of $\mathrm{RE}$ and hence the avoidance of the presumed risk of RE, the first studies investigating the effects of RE in cancer patients, regarding the risk of lymphedema in breast cancer patients [11] and the effects of moderate-intensity RE on the quality of life, body composition and muscular fitness in PCaP [12], were not published until 14 years later in 2003. Knowing the effects of RE in healthy subjects, PCaP on ADT seemed at the time to be the perfect target group for RE, meanwhile an assumption supported by ample evidence [13-15]. Indeed, 
the vast majority of studies investigating the effects of RE were conducted on $\mathrm{PCaP}$ receiving ADT. Specifically, RE alone or in combination with endurance exercise has been shown to improve the body composition, muscle strength, cardiovascular capacity, physical functioning and fatigue of PCaP [13-15]. Moreover, the first study on PCaP with bone metastatic disease was published in 2011 [16]. However, trials not excluding patients with bone metastatic disease, as well as those investigating the effects of free weight exercises, are still rare [13-15].

\section{Current Approach to Resistance Exercise in Prostate Cancer Patients}

\section{General Resistance Exercise Recommendations}

Although the influence of the modality, volume, intensity and frequency of RE has not been extensively studied in $\mathrm{PCaP}$, there is little evidence to suggest that the physiological response to RE, albeit often blunted due to ADT, is fundamentally different to that of healthy older individuals [17]. The exercise guidelines for cancer survivors published in 2019 recommend performing at least two sets of 8 to 12 repetitions at $60-75 \%$ of the one repetition maximum two to three times per week [18 $]$. This recommendation is only slightly more conservative than that for healthy novice trainees [19]. According to recent meta-analyses, training volume seems to be the primary driver of muscle hypertrophy, irrespective of training intensity, provided the sets are performed until failure $[20,21]$. However, the local muscular fatigue induced by low intensity contractions to failure might be more pronounced in older individuals $[22,23]$, conceivably leading to lower training volumes than would be accumulated with moderate- or high-load RE. In addition, high-load RE may be superior in improving functional performance than low-load RE, as measured by 30 -second chair stand performance, arm curl and grip strength [24]. Finally, research suggests that $\mathrm{PCaP}$ report higher training intensities than objectively measured [25], indicating a need for objective measurement of the administered training intensity, in order to provide effective stimuli.

Furthermore, protein supplementation should be considered in $\mathrm{PCaP}$ not suffering from chronic kidney disease, considering that the protein requirements of older adults may exceed the recommended amounts $[26,27]$ and given the synergistic effect of RE and protein supplementation across varying supplementation protocols [28 $8^{\bullet}$. Research on healthy adults supports spreading protein intake evenly throughout the day, with possible additional benefits of pre-sleep supplementation of slow-digesting protein, such as casein [29]. Creatine monohydrate supplementation should be considered as well, as it augments the response to $\mathrm{RE}[30,31 \bullet]$.
In practice, $\mathrm{PCaP}$ are not treated differently than healthy older adults, apart from a targeted approach to mitigating disease-specific needs and the consideration of diseasespecific risks. In our clinical experience, $\mathrm{PCaP}$ profit from patient empowerment and should be encouraged to perform their preferred mode of RE, provided that the principles of progressive overload are followed [19]. This is typically achieved by incremental increases in training intensity in the early stages of an RE intervention, as motor learning and neural adaptations take place $[32,33]$. Once a plateau is reached, the training frequency, and thus the training volume, is increased [20,34]. After a training frequency of three times per week is established, further progress is accomplished by an increase in the training volume [19,20], either by the addition of sets or supplementary exercises. This practical approach is summarized in Table 1.

\section{Disease-Specific Goals}

Although often confounded by older age, the negative effects of ADT on muscle strength, body composition, metabolic risk, bone health, physical functioning, fatigue and sexual health are well documented in the literature [5]. In addition, other PCa treatment options, such as surgery and radiotherapy, are often undertaken prior to beginning ADT and have been associated with urinary incontinence (UI), decreased sexual health and a reduced quality of life $[38,39]$.

As many of these treatment side effects are, at least in part, attenuated by RE, a concise overview of disease-specific goals of $\mathrm{RE}$ in $\mathrm{PCaP}$ is warranted.

\section{Improving Muscle Strength and Body Composition}

Significant increases in muscle strength and muscle mass with a concurrent decrease in fat mass have been found in $\mathrm{PCaP}$ $[15,40]$, as well as in patients with sarcopenic obesity [41] undertaking RE. Although the basic principles (progressive overload and exercise specificity) were followed in the majority of studies on PCaP, the optimal training method has yet to be determined [42]. Whether free weight training offers additional benefits for muscle strength and mass is not clear, with a single study finding a greater effect of free weight training on gains in triceps and leg strength in older adults [43•].

\section{Improving Bone Health and Reducing Fall and Fracture Risk}

The data on the effects of RE on bone mineral density (BMD) is heterogeneous, possibly due to different training methods used and differing responsiveness of the spine and femur to stimuli [44]. It is also possible, that BMD underestimates the extent of the adaptation of bones to loading [45]. Notwithstanding the above, research seems to indicate that 
Table 1 Practical approach to strength training in prostate cancer patients. $P C a$ prostate cancer, $R M$ maximum resistance that can be used for a given number of repetitions, $P F M$ pelvic floor muscle

\begin{tabular}{|c|c|c|c|c|c|c|c|}
\hline Exercise testing & $\begin{array}{l}\text { Resistance exercise } \\
\text { modality }\end{array}$ & Warm-up & Frequency & Intensity & Training volume & $\begin{array}{l}\text { Complementary } \\
\text { measures }\end{array}$ & $\begin{array}{l}\text { Additional } \\
\text { comment }\end{array}$ \\
\hline $\begin{array}{l}\text {-Consider testing for } \\
\text { common } \\
\text { symptoms of PCa } \\
\text { and its therapy } \\
{[18 \bullet]} \\
\text {-Exercise testing for } \\
\text { patients with a } \\
\text { history of } \\
\text { cardiovascular, } \\
\text { renal and } \\
\text { metabolic } \\
\text { symptoms [18•] } \\
\text {-Obtain medical } \\
\text { clearance for } \\
\text { patients with } \\
\text { cardiopulmonary } \\
\text { disease, bone } \\
\text { metastatic disease, } \\
\text { after } \\
\text { abdominal/lung } \\
\text { surgery and } \\
\text { ostomy, worsening } \\
\text { physical condition } \\
\text { and severe fatigue } \\
\text { or malnutrition, } \\
\text { consider referral to } \\
\text { specialist treatment } \\
\text { left [18•] }\end{array}$ & $\begin{array}{l}\text {-Full body training, } \\
\text { preferably } \\
\text { implementing } \\
\text { multiple-joint } \\
\text { exercises, if } \\
\text { feasible [19]. } \\
\text {-Otherwise, prescribe } \\
\text { exercises targeting } \\
\text { all major muscle } \\
\text { groups. } \\
\text {-Take pre-existing } \\
\text { musculoskeletal } \\
\text { issues into account } \\
\text {-Prevent loading parts } \\
\text { of skeleton } \\
\text { affected by } \\
\text { metastatic disease, } \\
\text { taking } \\
\text { co-contraction of } \\
\text { muscles in other } \\
\text { areas into account } \\
\text { (e.g., abdominal } \\
\text { wall muscles } \\
\text { during leg press) } \\
\text {-Ensure proper } \\
\text { breathing, } \\
\text { avoiding the } \\
\text { Valsalva maneuver }\end{array}$ & $\begin{array}{l}\text {-Start each } \\
\text { exercise by } \\
\text { performing } \\
\text { one or more } \\
\text { sets with a } \\
\text { lighter } \\
\text { resistance } \\
\text { prior to } \\
\text { beginning } \\
\text { work sets. } \\
\text {-Consider } \\
\text { non-specific } \\
\text { warm-up, } \\
\text { e.g., } \\
\text { 5-10 min of } \\
\text { low-intensity } \\
\text { aerobic } \\
\text { exercise }\end{array}$ & $\begin{array}{l}\text { Begin with } \\
\text { two } \\
\text { training } \\
\text { sessions } \\
\text { per week, } \\
\text { add one } \\
\text { session } \\
\text { when } \\
\text { progress } \\
\text { stagnates }\end{array}$ & $\begin{array}{l}\text { Begin at } \\
60 \% \text { of } \\
\text { the 1RM, } \\
\text { increase } \\
\text { up to } \\
80 \% \\
\text { depend- } \\
\text { ing on } \\
\text { tolerance } \\
{[19]} \\
\text {-If the 1RM } \\
\text { cannot be } \\
\text { determin- } \\
\text { ed, begin } \\
\text { with } \\
\text { 20RM, } \\
\text { progress } \\
\text { to 8RM }\end{array}$ & $\begin{array}{l}\text { Begin with two sets of } \\
15 \text { to } 20 \text { repetitions, } \\
\text { decreasing to } 8 \text { to } \\
12 \text { repetitions with } \\
\text { increasing load. } \\
\text { After increasing } \\
\text { training frequency, } \\
\text { add up to two sets } \\
\text { before adding } \\
\text { complementary } \\
\text { exercises }\end{array}$ & $\begin{array}{l}\text {-Consider } \\
\text { supplementi- } \\
\text { ng protein to } \\
\text { reach at least } \\
1.2 \mathrm{~g} / \mathrm{kg} \\
\text { bodyweight } \\
{[27,28 \cdot]} \\
\text {-Consider } \\
\text { supplementi- } \\
\text { ng } \\
\text { approximate- } \\
\text { ly } 5 \mathrm{~g} \text { of } \\
\text { creatine } \\
\text { monohydrate } \\
\text { per day [30, } \\
31 \bullet]\end{array}$ & $\begin{array}{l}\text {-For patients } \\
\text { with an } \\
\text { increased } \\
\text { risk of } \\
\text { falls, } \\
\text { consider } \\
\text { balance } \\
\text { training } \\
\text { [35•]. } \\
\text {-For patients } \\
\text { with } \\
\text { urinary } \\
\text { incontinen- } \\
\text { ce, } \\
\text { consider } \\
\text { PFM } \\
\text { training } \\
\text { [36•] } \\
\text {-For patients } \\
\text { with } \\
\text { osteoporo- } \\
\text { sis, } \\
\text { consider } \\
\text { impact } \\
\text { training } \\
{[37 \bullet]}\end{array}$ \\
\hline
\end{tabular}

interventions lasting at least 6-8 months and utilizing training intensities of at least $80 \%$ of the one repetition maximum are necessary to improve, or at least mitigate the loss of, BMD, with the spine being more responsive than the femoral neck $[44,46 \cdot$. Furthermore, free weight training might be superior to machine training in improving the BMD in the thoracic spine [47]. In PCaP on ADT, RE has been shown to positively affect BMD only in combination with impact training [13, 46•]. This finding is in line with research on postmenopausal bone loss [48].

The reduction of fall and thereby fracture risk by $R E$ is even less straightforward, nonetheless is RE an integral part of the exercise prescription for reducing fall and fracture risk, alongside balance and impact training [37•]. Indeed, the American Society of Clinical Oncology recommends RE for cancer survivors, especially those at greater risk of falling [49॰]. The main driver of the reduction of fall risk may be balance training; however, such programs are usually combined with RE [35•].

\section{Improving Physical Functioning and Reducing Fatigue}

Physical functioning, assessed by functional tests, is improved by RE in PCaP [15]. This is in line with data on older adults, which indicates improvements in physical ability, getting out of a chair and gait speed, with a significant reduction of pain in osteoarthritis patients [50]. Although the optimal method has yet to be determined, free weight training specifically might provide certain benefits for the elderly, as related to the performance of certain functional tests (chair stand, pan carry) [51].

The underlying mechanism in the development of cancerrelated fatigue is most likely multifactorial, with inflammation playing a significant role $[52,53]$. Research suggests that the positive effects of exercise are induced, at least in part, by the changes in levels of muscle-derived interleukin- 6 and downregulation of tumor necrosis factor alpha and interleukin-1 beta $[54,55]$. Patients suffering from cancer-related fatigue seem to benefit most from a combination of RE and AE, alongside other non-pharmacological interventions [56, 57]. In isolation, $\mathrm{RE}$ seems to be more effective than $\mathrm{AE}$ [58].

\section{Improving Cardiovascular Risk Factors}

Exercise interventions in general tend to improve cardiovascular risk factors in $\mathrm{PCaP}$ [59•]. The effects of $\mathrm{RE}$ in particular are inconclusive in this patient population, which might be a result of the negative effects of ADT or of an insufficient duration of RE interventions [42]. In healthy adults, 
medium- and long-term RE interventions have produced positive effects on blood pressure, fasting insulin levels and insulin resistance [60], with the latter two most probably owing predominantly to the improvement in body composition.

\section{Decreasing Incontinence}

Due to high efficacy, pelvic floor muscle (PFM) training is the primary form of therapy for UI in PCaP after radical prostatectomy [36]. Although general exercise may have a positive effect on the strength of PFM [61], the high prevalence of UI in female powerlifters [62] suggests that RE in isolation might not be sufficient to prevent UI. Although female athletes profit more from PFM training than non-athletic women [63], the question, whether RE and PFM training have a synergistic effect, especially in relation to $\mathrm{PCaP}$, remains to be answered.

\section{Improving the Quality of Life}

In $\mathrm{PCaP}$, positive effects on the quality of life have mostly been found in studies implementing a combination of RE and $\mathrm{AE}$ [64], corresponding to findings in breast cancer patients [65]. However, the quality of life has been described as the parameter least responsive to exercise interventions in the latter population [66]. In the studies investigating the effects of $\mathrm{RE}$ in PCaP, the quality of life was usually measured as a secondary outcome, implementing a number of questionnaires, such as the European Organisation for Research and Treatment of Cancer Quality of Life Questionnaires Core-30 and Prostate-25, Medical Outcomes Study Questionnaire Short Form36, Functional Assessment of Cancer TherapyGeneral and -Prostate, and the Patient Oriented Prostate Utility Scale-Psychometric. In view of the heterogeneity of intervention parameters and a potentially small effect size, it is difficult to ascertain the optimal method for this purpose.

As an important component of the quality of life, sexual health has received little attention in $\mathrm{PCaP}$ [13]. Although some aspects of sexual health have been reported to improve by the implementation of RE, further appropriately designed studies are necessary to ascertain the effects of RE on sexual health [13].

\section{Disease-Specific Risks}

The current consensus states that RE is generally safe for cancer survivors, even though adverse events might be under-reported in the literature [18]. This is similar to the findings in healthy older adults [50]. In a recent study on cancer patients undergoing cancer treatment, the combination of $\mathrm{RE}$ and $\mathrm{AE}$ was well tolerated, with the vast majority of adverse events consisting of minor musculoskeletal complaints [67]. However, it is worth noting that pain associated with knee osteoarthritis, a condition typically exacerbated by exercise, is mitigated by RE [68].

Although medical clearance is not recommended for all $\mathrm{PCaP}$ beginning gradually progressive $\mathrm{RE}$, as it would pose an unnecessary barrier to exercise, evaluation by a physician is indicated in patients suffering from comorbidities including (but not limited to) cardiopulmonary disease, bone metastatic disease, worsening physical condition and severe fatigue or malnutrition [18]. In order to remove the barriers to RE, the most dreaded potential complications of RE in $\mathrm{PCaP}$ are elaborated on below.

\section{Risk of Pathologic Fractures}

Approximately $70 \%$ of advanced PCaP develop bone metastatic disease, in the form of either osteoblastic, osteolytic, or mixed lesions [69]. Although the overall appearance of osteoblastic lesions suggests areas of increased density, the newly formed, radio-dense tissue consist mostly of immature bone and is prone to mechanical failure $[69,70]$. These findings are especially troubling considering the reduced $\mathrm{BMD}$ in $\mathrm{PCaP}$ on ADT [71]. The prevalence of skeletal-related events is high in patients with metastatic castration resistant $\mathrm{PCa}$ and the risk thereof is increased by high baseline prostate-specific antigen, a high number of metastatic lesions, rapidly increasing prostate-specific antigen and progression of $\mathrm{PCa}$ [72].

Conversely, RE interventions have been successfully administered in PCaP with bone metastatic disease $[16,73,74]$. Bone metastatic disease should therefore not be seen as an insurmountable obstacle to clinically supervised RE, provided the avoidance of direct loading of affected bones [75]. Concurrent contraction of antagonistic, often stabilizing, muscles should also be taken into account, as the resulting forces on the bone may be considerably increased [76, 77].

A number of scores have been developed in hope of quantifying the fracture risk in bone metastatic disease, such as Mirels' score for long bones [78] and the Spinal Instability Neoplastic Score for the spine [79]. However, the reliability of these scores remains a matter of considerable debate [80] and the referral of afflicted patients to trained personnel is recommended [18•].

\section{Risk of Cardiovascular Events and Hypoglycemia}

During RE, the systolic and, to a lesser extent, diastolic arterial blood pressure increases significantly, this response being magnified by the Valsalva maneuver [81]. The magnitude of the increase, however, seems to correlate more with the relative load lifted, rather than the absolute load, with bilateral exercises being more potent than unilateral exercises [82]. Interestingly, in people with hypertension, the systolic blood pressure may increase significantly more when performing a set to failure with $40 \%$ of the one repetition maximum, than 
with $80 \%$ [83]. The Valsalva maneuver, consisting of (attempted) forceful expiration against a closed glottis, seems to increase muscle activation and thus strength, yet possibly not to a greater extent than forceful expiration [84].

Training experience also seems to play a role in the cardiovascular response to $\mathrm{RE}$, with experienced trainees displaying a blunted increase in the systolic blood pressure, compared to novices [85]. Correspondingly, the American Heart Association does not recommend exercise testing prior to initiating RE for people with stable medical conditions, provided the participants begin with a low to moderate intensity of RE [86]. Nevertheless, most recommendations concerning testing prior to initiating exercise seem to be based on findings in $\mathrm{AE}$ [87].

In people with hypertension, RE appears to be safe, with pre-exercise testing recommended for people with known disease [88]. However, in a recent systematic review and metaanalysis on the effects of RE in people with coronary heart disease, although presumably under-reported, 63 of 64 cardiovascular adverse events were associated with complementary $\mathrm{AE}$ and exercise testing, not RE [89]. Furthermore, in patients with heart failure, RE appears safe, as it does not result in reduced cardiac function, while effectively improving oxygen uptake [90]. In cancer survivors, even high intensity $\mathrm{AE}$ and $\mathrm{RE}$ were associated with a low risk of adverse events [91•].

The risk of hypoglycemia has not been investigated thoroughly in PCaP. It should be noted, however, that it does not seem to be excessive in patients with type 2 diabetes, although studies investigating this topic are rare [92]. In individuals with impaired fasting glucose, RE appears to exert an acute, volume- and intensity-dependent lowering effect on fasting blood glucose [93]. Concerning longer interventions in patients with type 2 diabetes, AE and RE seem to bear a similar risk of hypoglycemia [92].

\section{Risk of Worsening Lymphedema}

Lower extremity lymphedema is a rare complication of the surgical treatment of $\mathrm{PCa}$, occurring in approximately $4 \%$ of PCaP after extended pelvic lymph node dissection [94]. Whether lymphedema can be exacerbated by RE has as of date not been investigated in PCaP. In breast cancer patients, $\mathrm{RE}$ does not seem to exacerbate upper extremity edema, potentially even decreasing it [95•]. The exercise recommendation regarding lower extremity lymphedema includes light $\mathrm{AE}$ and strengthening the calf muscles [96]. In addition, general recommendations for the therapy of secondary lymphedema in cancer patients include RE [97].

\section{Conclusions}

In PCa patients, RE has been well-researched and the data are clear that it is beneficial in multiple ways. Future directions should look at the long-term effects of RE, including mortality and relapse, as well as implementation of exercise programs.

Funding Open Access funding provided by Medical University of Vienna.

\section{Declarations}

Conflict of Interest None of the authors has any potential conflicts of interest to disclose.

Human and Animal Rights and Informed Consent This article does not contain any studies with human or animal subjects performed by any of the authors.

Open Access This article is licensed under a Creative Commons Attribution 4.0 International License, which permits use, sharing, adaptation, distribution and reproduction in any medium or format, as long as you give appropriate credit to the original author(s) and the source, provide a link to the Creative Commons licence, and indicate if changes were made. The images or other third party material in this article are included in the article's Creative Commons licence, unless indicated otherwise in a credit line to the material. If material is not included in the article's Creative Commons licence and your intended use is not permitted by statutory regulation or exceeds the permitted use, you will need to obtain permission directly from the copyright holder. To view a copy of this licence, visit http://creativecommons.org/licenses/by/4.0/.

\section{References}

Papers of particular interest, published recently, have been highlighted as:

- Of importance

•- Of major importance

1. New Global Cancer Data: GLOBOCAN 2018 | UICC [Internet]. [cited 2020 Oct 28]. Available from: https://www.uicc.org/news/ new-global-cancer-data-globocan-2018

2. Golubnitschaja O, Topolcan O, Kucera R, Costigliola V, Akopyan M, Akulov SN, et al. 10th Anniversary of the European Association for Predictive, Preventive and Personalised (3P) Medicine-EPMA World Congress Supplement 2020. EPMA J [Internet]. 2020;11:1133. Available from. 2020. https://doi.org/10.1007/s13167-02000206-1.

3. Culp MB, Soerjomataram I, Efstathiou JA, Bray F, Jemal A. Recent global patterns in prostate cancer incidence and mortality rates. Eur Urol [Internet]. 2020;77:38-52 Available from: http://www. sciencedirect.com/science/article/pii/S0302283819306190 This article describes the recent changes in prostate cancer incidence and mortality rates.

4. Gupta D, Chuy KL, Yang JC, Bates M, Lombardo M, Steingart RM. Cardiovascular and metabolic effects of androgen-deprivation therapy for prostate cancer. J Oncol Pract. 2018;14:580-7.

5. Nguyen PL, Alibhai, SMH, Basaria S, D'Amico A V, Kantoff PW, Keating NL, et al. Adverse effects of androgen deprivation therapy and strategies to mitigate them. Eur Urol [Internet]. European Association of Urology; 2015;67:825-836. Available from: http:// linkinghub.elsevier.com/retrieve/pii/S0302283814006502 
6. Muniyan S, Xi L, Datta K, Das A, Teply BA, Batra SK, et al. Cardiovascular risks and toxicity-the Achilles heel of androgen deprivation therapy in prostate cancer patients. Biochim Biophys Acta - Rev Cancer [Internet]. 2020;1874:188383. Available from: http://www.sciencedirect.com/science/article/pii/ S0304419X20301025

7. Epstein MM, Edgren G, Rider JR, Mucci LA, Adami H-O. Temporal trends in cause of death among Swedish and US men with prostate cancer. J Natl Cancer Inst. 2012;104:1335-42.

8. Daskivich TJ, Fan K-H, Koyama T, Albertsen PC, Goodman M, Hamilton AS, et al. Effect of age, tumor risk, and comorbidity on competing risks for survival in a U.S. population-based cohort of men with prostate cancer. Ann Intern Med. 2013;158:709-17.

9. Winningham ML, MacVicar MG, Bondoc M, Anderson JI, Minton JP. Effect of aerobic exercise on body weight and composition in patients with breast cancer on adjuvant chemotherapy. Oncol Nurs Forum. 1989;16:683-9.

10. MacVicar MG, Winningham ML, Nickel JL. Effects of aerobic interval training on cancer patients' functional capacity. Nurs Res. 1989;38:348-51

11. McKenzie DC, Kalda AL. Effect of upper extremity exercise on secondary lymphedema in breast cancer patients: a pilot study. $\mathrm{J}$ Clin Oncol [Internet]. 2003;21:463-6. Available from. http://www. ncbi.nlm.nih.gov/pubmed/12560436.

12. Segal RJ. Resistance exercise in men receiving androgen deprivation therapy for prostate cancer. J Clin Oncol [Internet]. 2003;21: 1653-9. Available from:. http://www.jco.org/cgi/doi/10.1200/JCO. 2003.09.534

13. Zdravkovic A, Hasenöhrl T, Palma S, Crevenna R. Effects of resistance exercise in prostate cancer patients: a systematic review update as of March 2020. Wien Klin Wochenschr. 2020;132:452-63.

14. Hasenoehrl T, Keilani M, Sedghi Komanadj T, Mickel M, Margreiter M, Marhold M, et al. The effects of resistance exercise on physical performance and health-related quality of life in prostate cancer patients: a systematic review. Support Care Cancer [Internet]. 2015;23:2479-97. Available from. http://www.ncbi. nlm.nih.gov/pubmed/26003426.

15. Keilani M, Hasenoehrl T, Baumann L, Ristl R, Schwarz M, Marhold M, et al. Effects of resistance exercise in prostate cancer patients: a meta-analysis. Support Care Cancer. Supportive Care in Cancer. 2017;25:2953-68.

16. Galvão DA, Taaffe DR, Cormie P, Spry N, Chambers SK, PeddleMcIntyre C, et al. Efficacy and safety of a modular multi-modal exercise program in prostate cancer patients with bone metastases: a randomized controlled trial. BMC Cancer. 2011;11

17. Hanson ED, Nelson AR, West DWD, Violet JA, O'Keefe L, Phillips SM, et al. Attenuation of resting but not load-mediated protein synthesis in prostate cancer patients on androgen deprivation. J Clin Endocrinol Metab. 2017;102:1076-83.

18. Campbell KL, Winters-Stone KM, Wiskemann J, May AM, Schwartz AL, Courneya KS, et al. Exercise guidelines for cancer survivors: consensus statement from International Multidisciplinary Roundtable. Med Sci Sports Exerc [Internet]. 2019;51:2375-90 Available from: http://www.ncbi.nlm.nih.gov/ pubmed/31626055 This is the most recent consensus statement concerning exercise guidelines for cancer survivors.

19. Medicine AC of S. American College of Sports Medicine position stand. Progression models in resistance training for healthy adults. Med Sci Sports Exerc [Internet]. 2009;41:687-708. Available from: http://content.wkhealth.com/linkback/openurl?sid=WKPTLP: landingpage \&an $=00005768-200903000-00026$

20. Schoenfeld BJ, Ogborn D, Krieger JW. Dose-response relationship between weekly resistance training volume and increases in muscle mass: a systematic review and meta-analysis. J Sports Sci. 2017;35: $1073-82$.
21. Csapo R, Alegre LM. Effects of resistance training with moderate vs heavy loads on muscle mass and strength in the elderly: a metaanalysis. Scand J Med \&amp. Sci Sport. 2016;26:995-1006.

22. Yoon T, De-Lap BS, Griffith EE, Hunter SK. Age-related muscle fatigue after a low-force fatiguing contraction is explained by central fatigue. Muscle and Nerve. 2008;37:457-66.

23. Russ DW, Towse TF, Wigmore DM, Lanza IR, Kent-Braun JA. Contrasting influences of age and sex on muscle fatigue. Med Sci Sports Exerc. 2008;40:234-41.

24. Richardson DL, Duncan MJ, Jimenez A, Juris PM, Clarke ND. Effects of movement velocity and training frequency of resistance exercise on functional performance in older adults: a randomised controlled trial. Eur J Sport Sci. 2019;19:234-46.

25. Smith L, Lee JA, Mun J, Pakpahan R, Imm KR, Izadi S, et al. Levels and patterns of self-reported and objectively-measured free-living physical activity among prostate cancer survivors: a prospective cohort study. Cancer. 2019;125:798-806.

26. Courtney-Martin G, Ball RO, Pencharz PB, Elango R. Protein requirements during aging. Nutrients. 2016;8.

27. Franzke B, Neubauer O, Cameron-Smith D, Wagner K-H. Dietary protein, muscle and physical function in the very old. Nutrients. 2018;10.

28. Liao C-D, Tsauo J-Y, Wu Y-T, Cheng C-P, Chen H-C, Huang Y-C, et al. Effects of protein supplementation combined with resistance exercise on body composition and physical function in older adults: a systematic review and meta-analysis. Am J Clin Nutr. 2017;106: 1078-91 This is a recent systematic review and meta-analysis on the combination of protein supplementation and resistance exercise in older patients, suggesting a synergistic effect.

29. Jäger R, Kerksick CM, Campbell BI, Cribb PJ, Wells SD, Skwiat TM, et al. International Society of Sports Nutrition Position Stand: protein and exercise. J Int Soc Sports Nutr. 2017;14:20.

30. Devries MC, Phillips SM. Creatine supplementation during resistance training in older adults-a meta-analysis. Med Sci Sports Exerc. 2014;46:1194-203.

31. Stares A, Bains M. The additive effects of creatine supplementation and exercise training in an aging population: a systematic review of randomized controlled trials. J Geriatr Phys Ther. 2020;43:99-112 This is a recent systematic review on the combination of creatine supplementation and resistance exercise in older patients, suggesting a synergistic effect.

32. Folland JP, Williams AG. The adaptations to strength training: Morphological and neurological contributions to increased strength. Sport Med. 2007;37:145-68.

33. Del Vecchio A, Casolo A, Negro F, Scorcelletti M, Bazzucchi I, Enoka R, et al. The increase in muscle force after 4 weeks of strength training is mediated by adaptations in motor unit recruitment and rate coding. J Physiol. 2019;597:1873-87.

34. Schoenfeld BJ, Ogborn D, Krieger JW. Effects of resistance training frequency on measures of muscle hypertrophy: a systematic review and meta-analysis. Sport Med. 2016;46:1689-97.

35. Sherrington C, Fairhall NJ, Wallbank GK, Tiedemann A, Michaleff ZA, Howard K, et al. Exercise for preventing falls in older people living in the community. Cochrane Database Syst Rev. 2019;2019 This is the most recent Cochrane systematic review on the effectiveness of exercise in reducing the risk of falls in the elderly.

36. Strączyńska A, Weber-Rajek M, Strojek K, Piekorz Z, Styczyńska $\mathrm{H}$, Goch A, et al. The impact of pelvic floor muscle training on urinary incontinence in men after radical prostatectomy (RP)-a systematic review. Clin Interv Aging. 2019;14:1997-2005 This is a recent systematic review on the effectiveness of pelvic floor muscle training for the treatment of urinary incontinence in prostate cancer patients after radical prostatectomy.

37. Beck BR, Daly RM, Singh MAF, Taaffe DR. Exercise and Sports Science Australia (ESSA) position statement on exercise prescription for the prevention and management of osteoporosis. J Sci Med 
Sport [Internet]. 2017;20:438-45 Available from: http://www. sciencedirect.com/science/article/pii/S1440244016302171 This is a recent position statement on the implementation of exercise to combat osteoporosis.

38. Wolff RF, Ryder S, Bossi A, Briganti A, Crook J, Henry A, et al. A systematic review of randomised controlled trials of radiotherapy for localised prostate cancer. Eur J Cancer. 2015;51:2345-67.

39. Lardas M, Liew M, van den Bergh RC, De Santis M, Bellmunt J, Van den Broeck T, et al. Quality of life outcomes after primary treatment for clinically localised prostate cancer: a systematic review. Eur Urol. 2017;72:869-85.

40. Padilha CS, Marinello PC, Galvão DA, Newton RU, Borges FH, Frajacomo F, et al. Evaluation of resistance training to improve muscular strength and body composition in cancer patients undergoing neoadjuvant and adjuvant therapy: a meta-analysis. J Cancer Surviv. 2017;11:339-49.

41. Hsu K-J, Liao C-D, Tsai M-W, Chen C-N. Effects of exercise and nutritional intervention on body composition, metabolic health, and physical performance in adults with sarcopenic obesity: a metaanalysis. Nutrients. 2019;11.

42. Keilani M, Hasenoehrl T, Baumann L, Ristl R, Schwarz M, Marhold M, et al. Effects of resistance exercise in prostate cancer patients: a meta-analysis. Support Care Cancer. 2017;25:2953-68.

43. Schott N, Johnen B, Holfelder B. Effects of free weights and machine training on muscular strength in high-functioning older adults. Exp Gerontol. 2019;122:15-24 This study found some additional benefits of free-weight resistance exercise alongside high acceptance levels in older individuals.

44. Hong AR, Kim SW. Effects of resistance exercise on bone health. Endocrinol Metab. 2018;33:435-44.

45. Järvinen TLN, Kannus P, Sievänen H. Have the DXA-based exercise studies seriously underestimated the effects of mechanical loading on bone? J Bone Miner Res [Internet]. John Wiley \& Sons, Ltd; 1999;14:1634-5. Available from. 1999. https://doi.org/ 10.1359/jbmr.1999.14.9.1634.

46. Bressi B, Cagliari M, Contesini M, Mazzini E, Bergamaschi FAM, Moscato A, et al. Physical exercise for bone health in men with prostate cancer receiving androgen deprivation therapy: a systematic review. Support Care Cancer. 2020; This is the most recent systematic review regarding the effects of exercise on bone health, specific to prostate cancer patients.

47. Shojaa M, von Stengel S, Kohl M, Schoene D, Kemmler W. Effects of dynamic resistance exercise on bone mineral density in postmenopausal women: a systematic review and meta-analysis with special emphasis on exercise parameters. Osteoporos Int. 2020;31:142744.

48. Zhao R, Zhao M, Xu Z. The effects of differing resistance training modes on the preservation of bone mineral density in postmenopausal women: a meta-analysis. Osteoporos Int. 2015;26:1605-18.

49. Shapiro CL, Van Poznak C, Lacchetti C, Kirshner J, Eastell R, Gagel R, et al. Management of osteoporosis in survivors of adult cancers with nonmetastatic disease: ASCO clinical practice guideline. J Clin Oncol. 2019;37:2916-46.

50. Liu C-J. Latham NK. Cochrane Database Syst Rev: Progressive resistance strength training for improving physical function in older adults; 2009.

51. Balachandran A, Martins MM, De Faveri FG, Alan O, Cetinkaya F, Signorile JF. Functional strength training: seated machine vs standing cable training to improve physical function in elderly. Exp Gerontol. 2016;82:131-8.

52. Bower JE. Cancer-related fatigue-mechanisms, risk factors, and treatments. Nat Rev Clin Oncol [Internet]. 2014;11:597-609 Available from: http://www.ncbi.nlm.nih.gov/pubmed/25113839.

53. Bower JE. The role of neuro-immune interactions in cancer-related fatigue: biobehavioral risk factors and mechanisms. Cancer. 2019;125:353-64.
54. Wood LJ, Nail LM, Winters KA. Does muscle-derived interleukin6 mediate some of the beneficial effects of exercise on cancer treatment-related fatigue? Oncol Nurs Forum [Internet]. 2009;36: 519-24. Available from: http://onf.ons.org/onf/36/5/does-musclederived-interleukin-6-mediate-some-beneficial-effects-exercisecancer-treatment

55. Pedersen BK, Febbraio MA. Muscle as an endocrine organ: focus on muscle-derived interleukin-6. Physiol Rev. 2008;88:1379-406.

56. Nakano J, Hashizume K, Fukushima T, Ueno K, Matsuura E, Ikio $\mathrm{Y}$, et al. Effects of aerobic and resistance exercises on physical symptoms in cancer patients: a meta-analysis. Integr Cancer Ther. 2018;17:1048-58.

57. Hilfiker R, Meichtry A, Eicher M, Nilsson Balfe L, Knols RH, Verra ML, et al. Exercise and other non-pharmaceutical interventions for cancer-related fatigue in patients during or after cancer treatment: a systematic review incorporating an indirectcomparisons meta-analysis. Br J Sports Med. 2018;52:651-8.

58. Baguley BJ, Bolam KA, Wright ORL, Skinner TL. The effect of nutrition therapy and exercise on cancer-related fatigue and quality of life in men with prostate cancer: a systematic review. Nutrients. 2017;9.

59. Bigaran A, Zopf E, Gardner J, La Gerche A, Murphy DG, Howden EJ, et al. The effect of exercise training on cardiometabolic health in men with prostate cancer receiving androgen deprivation therapy: a systematic review and meta-analysis. Prostate Cancer Prostatic Dis. 2020; This is the most recent systematic review and metaanalysis concerning the effects of exercise interventions on cardiometabolic risk factors in prostate cancer patients.

60. Ashton RE, Tew GA, Aning JJ, Gilbert SE, Lewis L, Saxton JM. Effects of short-term, medium-term and long-term resistance exercise training on cardiometabolic health outcomes in adults: systematic review with meta-analysis. Br J Sports Med. 2020;54:341-8.

61. Bø K. Urinary incontinence, pelvic floor dysfunction, exercise and sport. Sport Med. 2004;34:451-64.

62. Wikander L, Cross D, Gahreman DE. Prevalence of urinary incontinence in women powerlifters: a pilot study. Int Urogynecol J. 2019;30:2031-9.

63. Sorrigueta-Hernández A, Padilla-Fernandez B-Y, MarquezSanchez M-T, Flores-Fraile M-C, Flores-Fraile J, Moreno-Pascual $\mathrm{C}$, et al. Benefits of physiotherapy on urinary incontinence in highperformance female athletes. Meta-analysis. J Clin Med [Internet]. MDPI AG; 2020 [cited 2020 Nov 27];9:3240. Available from: https://www.mdpi.com/2077-0383/9/10/3240

64. Teleni L, Chan RJ, Chan A, Isenring EA, Vela I, Inder WJ, et al. Exercise improves quality of life in androgen deprivation therapytreated prostate cancer: systematic review of randomised controlled trials. Endocr Relat Cancer. 2016;23:101-12.

65. Zhang X, Li Y, Liu D. Effects of exercise on the quality of life in breast cancer patients: a systematic review of randomized controlled trials. Support Care Cancer. 2019;27:9-21.

66. Gebruers N, Camberlin M, Theunissen F, Tjalma W, Verbelen H, Van Soom T, et al. The effect of training interventions on physical performance, quality of life, and fatigue in patients receiving breast cancer treatment: a systematic review. Support Care Cancer. 2019;27:109-22.

67. Henriksson A, Johansson B, Radu C, Berntsen S, Igelström H, Nordin K. Is it safe to exercise during oncological treatment? A study of adverse events during endurance and resistance trainingdata from the Phys-Can study. Acta Oncol (Madr) [Internet]. Taylor \& Francis; 2020;1-10. Available from. 2021. https://doi.org/10. 1080/0284186X.2020.1851046.

68. Li Y, Su Y, Chen S, Zhang Y, Zhang Z, Liu C, et al. The effects of resistance exercise in patients with knee osteoarthritis: a systematic review and meta-analysis. Clin Rehabil. 2016;30:947-59.

69. Hensel J, Thalmann GN. Biology of bone metastases in prostate cancer. Urology. 2016;92:6-13. 
70. Whyne CM. Biomechanics of metastatic disease in the vertebral column. Neurol Res. 2014;36:493-501.

71. Nguyen PL, Alibhai SMH, Basaria S, D'Amico AV, Kantoff PW, Keating NL, et al. Adverse effects of androgen deprivation therapy and strategies to mitigate them. Eur Urol. 2015;67:825-36.

72. Gartrell BA, Saad F. Pathologic fracture in patients with metastatic prostate cancer. Curr Opin Urol. 2014;24:595-600.

73. Cormie P, Newton RU, Spry N, Joseph D, Taaffe DR, Galvão DA. Safety and efficacy of resistance exercise in prostate cancer patients with bone metastases. Prostate Cancer Prostatic Dis [Internet]. 2013;16:328-35. https://doi.org/10.1038/pcan.2013.22.

74. Galvão DA, Taaffe DR, Spry N, Cormie P, Joseph D, Chambers SK, et al. Exercise preserves physical function in prostate cancer patients with bone metastases. Med Sci Sports Exerc [Internet]. 2018;50:393-9. Available from. http://www.ncbi.nlm.nih.gov/ pubmed/29036016.

75. Hart NH, Galvão DA, Newton RU. Exercise medicine for advanced prostate cancer. Curr Opin Support Palliat Care. 2017;11:247-57.

76. Rohlmann A, Pohl D, Bender A, Graichen F, Dymke J, Schmidt H, et al. Activities of everyday life with high spinal loads. PLoS One. 2014;9:e98510.

77. Van Dieën JH, Kingma I, Van Der Bug JCE. Evidence for a role of antagonistic cocontraction in controlling trunk stiffness during lifting. J Biomech. 2003;36:1829-36.

78. Mirels H. Metastatic disease in long bones. A proposed scoring system for diagnosing impending pathologic fractures. Clin Orthop Relat Res. 1989:256-64.

79. Fourney DR, Frangou EM, Ryken TC, DiPaola CP, Shaffrey CI, Berven SH, et al. Spinal instability neoplastic score: an analysis of reliability and validity from the spine Oncology Study Group. J Clin Oncol. 2011;29:3072-7.

80. Bailey S, Hackney D, Vashishth D, Alkalay RN. The effects of metastatic lesion on the structural determinants of bone: current clinical and experimental approaches. Bone. 2020;138:115159.

81. Hackett DA, Chow C-M. The valsalva maneuver: its effect on intraabdominal pressure and safety issues during resistance exercise. $\mathrm{J}$ Strength Cond Res. 2013;27:2338-45.

82. McCartney N. Acute responses to resistance training and safety. Med Sci Sports Exerc. 1999;31:31-7.

83. Nery SS, Gomides RS, da Silva GV, Forjaz CLM, Mion D Jr, Tinucci T. Intra-arterial blood pressure response in hypertensive subjects during low- and high-intensity resistance exercise. Clinics. 2010;65:271-7.

84. Ikeda ER, Borg A, Brown D, Malouf J, Showers KM, Li S. The valsalva maneuver revisited: the influence of voluntary breathing on isometric muscle strength. J Strength Cond Res. 2009;23:12732.

85. Fleck SJ, Dean LS. Resistance-training experience and the pressor response during resistance exercise. J Appl Physiol. 1987;63:11620.

86. Williams MA, Haskell WL, Ades PA, Amsterdam EA, Bittner V, Franklin BA, et al. Resistance exercise in individuals with and without cardiovascular disease: 2007 update: a scientific statement from the American Heart Association Council on Clinical
Cardiology and Council on Nutrition, Physical Activity, and Metabolism. Circulation. 2007;116:572-84.

87. Fletcher GF, Ades PA, Kligfield P, Arena R, Balady GJ, Bittner VA, et al. Exercise standards for testing and training: a scientific statement from the American heart association. Circulation. 2013;128:873-934.

88. Sharman JE, La Gerche A, Coombes JS. Exercise and cardiovascular risk in patients with hypertension. Am J Hypertens. 2015;28: $147-58$

89. Hollings M, Mavros Y, Freeston J, Fiatarone SM. The effect of progressive resistance training on aerobic fitness and strength in adults with coronary heart disease: a systematic review and metaanalysis of randomised controlled trials. Eur J Prev Cardiol. 2017;24:1242-59.

90. Santos FV, Chiappa GR, Ramalho SHR, de Lima ACGB, de Souza FSJ, Cahalin LP, et al. Resistance exercise enhances oxygen uptake without worsening cardiac function in patients with systolic heart failure: a systematic review and meta-analysis. Heart Fail Rev. 2018:23:73-89.

91. Toohey K, Pumpa K, McKune A, Cooke J, Semple S. Highintensity exercise interventions in cancer survivors: a systematic review exploring the impact on health outcomes. J Cancer Res Clin Oncol. 2018;144 This recent systematic review found positive effects of high-intensity exercise and a low risk of adverse events in cancer survivors.

92. Yang Z, Scott CA, Mao C, Tang J, Farmer AJ. Resistance exercise versus aerobic exercise for type 2 diabetes: a systematic review and meta-analysis. Sport Med. 2014;44:487-99.

93. Black LE, Swan PD, Alvar BA. Effects of intensity and volume on insulin sensitivity during acute bouts of resistance training. J Strength Cond Res. 2010;24:1109-16.

94. Clark T, Parekh DJ, Cookson MS, Chang SS, Smith ER Jr, Wells $\mathrm{N}$, et al. Randomized prospective evaluation of extended versus limited lymph node dissection in patients with clinically localized prostate cancer. J Urol. 2003;169:145-8.

95. Hasenoehrl T, Palma S, Ramazanova D, Kölbl H, Dorner TE, Keilani M, et al. Resistance exercise and breast cancer-related lymphedema - a systematic review update and meta-analysis. Support Care Cancer. 2020;28:3593-603 This is the most recent systematic review and meta-analysis on the effects of resistance exercise in breast cancer-related lymphedema and likely the first to disprove, by a quantification of the results of homogeneous assessment methods, a commonly held belief in the risk of worsening of cancer-related edema due to resistance exercise.

96. Ratchford EV, Evans NS. Approach to lower extremity edema. Curr Treat Options Cardiovasc Med. 2017;19:16.

97. Backler C, Beck M, Poage E. Clinical summary of the ons guidelines $^{\mathrm{TM}}$ for cancer treatment-related lymphedema. Clin J Oncol Nurs. 2020;24:566-70.

Publisher's Note Springer Nature remains neutral with regard to jurisdictional claims in published maps and institutional affiliations. 